DEPÓSITO LEGAL ZU2020000153

Esta publicación científica en formato digital

es continuidad de la revista impresa

ISSN 0041-8811

E-ISSN 2665-0428

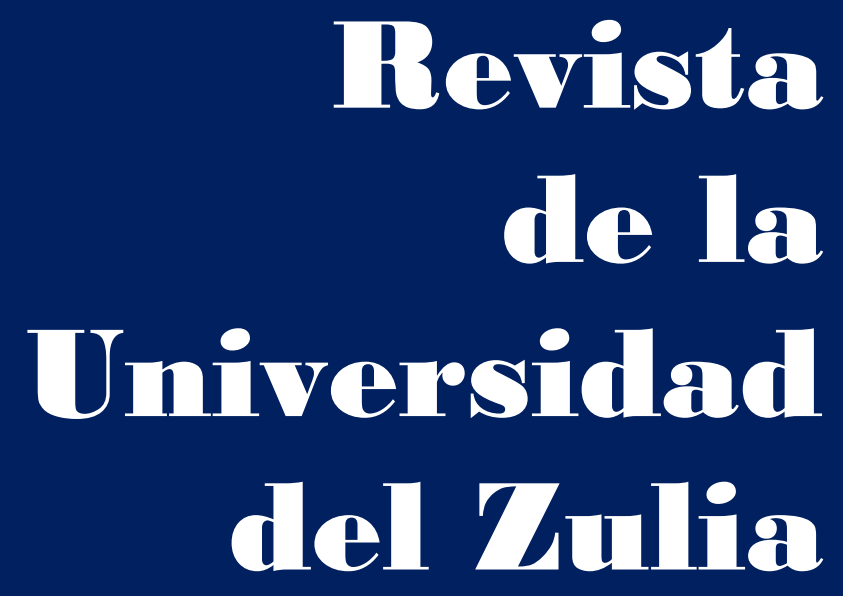

Fundada en 1947

por el Dr. Jesús Emrique Lossada

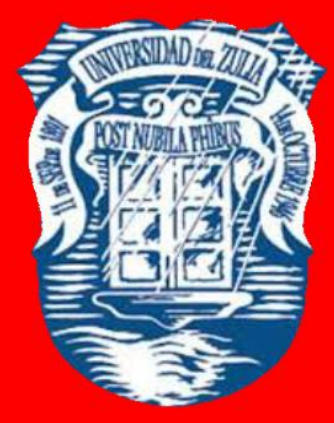

Ciencias

Sociales

y Arte

Año $12 \quad N^{\circ} 34$

Septiembre - Diciembre 2021

Tercera Época

Maracaibo-Veneruela 


\title{
Heterogeneity of signs and classification criteria for compound words
}

\author{
Marzhan U. Suleibanova * \\ Lyudmila M. Dudarova ** \\ Marziyat M. Bidanok ***
}

ABSTRACT

The purpose of the article is to draw attention to the fact of the development of compositology in languages of different grammatical structures and in the Iberian-Caucasian in particular. We used classification, descriptive methods, linguistic analysis techniques, which are widely used by all researchers who work with the material of specific languages or linguistic groups. The method of typological comparison used in this study should be especially highlighted, which confirms the sufficient efficiency when comparing languages of different genetic and structural affiliation. The main and easily established difference when comparing the word-formation systems of the Chechen and Russian, for example, languages, is that in the Chechen language, of the two main ways of forming words (word production and base formation), the second clearly predominates. The reliance of the Chechen wordformation on the basis is not a new phenomenon and not a specificity of the Chechen language. It is known that in many languages, word-formation affixes historically go back to the components of additions. Consequently, compounding precedes affixation. Composites in Nakh languages go back to syntactic combinations of words and the most acceptable for the Chechen language is the classification according to the method of their formation.

KEY WORDS: classification and typologization of complex words; heterogeneity of features of composites; derivational systems of the Chechen and Russian languages.

*Doctor of Philology, Professor of the Russian Language Department, Chechen State University. ORCID: https://orcid.org/0000-0003-3956-0227. E-mail: sulejbanova.ru@mail.ru

${ }^{* *}$ Candidate of Philological Sciences, Professor, Head of the Russian language department Ingush State University. ORCID: https://orcid.org/0000-0002-6429-2669. E-mail: lyuda.dudarova@mail.ru

***Doctor of Philology, Deputy Director for Science, Adyghe Republican Institute for Humanitarian Research named after T.M. Kerashev. ORCID: https://orcid.org/0000-00017401-0736. E-mail: marziyatbidanok@mail.ru 


\section{Heterogeneidad de signos y criterios de clasificación para palabras compuestas}

RESUMEN

El objetivo del artículo es llamar la atención sobre el hecho del desarrollo de la compositología en lenguas de diferentes estructuras gramaticales y en el ibéricocaucásico en particular. Se utilizaron técnicas de clasificación, métodos descriptivos, análisis lingüístico, que son ampliamente utilizadas por todos los investigadores que trabajan con el material de lenguas o grupos lingüísticos específicos. Cabe destacar especialmente el método de comparación tipológica utilizado en este estudio, que confirma la eficacia suficiente a la hora de comparar lenguas de diferente filiación genética y estructural. La principal y fácilmente establecida diferencia al comparar los sistemas de formación de palabras de los idiomas checheno y ruso, por ejemplo, es que en el idioma checheno, de las dos formas principales de formar palabras (producción de palabras y formación de bases), predomina claramente la segunda. La dependencia de la formación de la palabra chechena en la base no es un fenómeno nuevo ni una especificidad de la lengua chechena. Se sabe que, en muchos idiomas, los afijos de formación de palabras históricamente se remontan a los componentes de las adiciones. En consecuencia, la composición precede a la colocación. Los compuestos en lenguas nakh se remontan a combinaciones sintácticas de palabras y la más aceptable para la lengua chechena es la clasificación según el método de su formación.

PALABRAS CLAVE: clasificación y tipificación de palabras complejas; heterogeneidad de las características de los compuestos; sistemas derivacionales de las lenguas chechena y rusa.

\section{Introduction}

Among the numerous languages of the peoples of the Caucasus, there are languages that have been studied relatively poorly. These include Chechen and other Nakh languages.

There are still many questions, linguistic units and categories in Nakh linguistics that have not been fully studied. The sphere of word formation and especially composite word formation stands out in this group of questions.

Thus, the relevance of this study is explained by: first, the need for a comprehensive study of the poorly studied word-formation system of the Chechen and other Nakh languages in general; secondly, in the opinion of most researchers, insufficient knowledge of the 
fundamental structure, which is the main way of forming words in Chechen and other Nakh (and in general Caucasian) languages; thirdly, the need to solve a number of problems of practical grammar, especially those associated with the differentiation of complex words, phrases and spelling of complex words.

The classifiability of language units varies, and according to many researchers, compound words are particularly distinguished in this regard: "We will always try to build classifications, but it should be borne in mind that compound words are not a category that meets the classification requirements well and are unlikely to be classified at all" (Marchand, 1960).

The problem of classification and typology of compound words is associated with certain difficulties of both structural and semantic order. The diversity and heterogeneity of features and criteria for classifying compound words in General linguistic terms sometimes face a similar variety of linguistic reality, which imposes additional difficulties that prevent the creation of a unified classification scheme for compound words that would fit all languages and meet the requirements for the classification of language units.

The task of the researcher is to correctly reveal the commonality and difference of elements, based on the common principles of a particular classification.

In our opinion, it is advisable to choose such of the existing classification principles that can somehow help to reveal the material nature, semantic essence and degree of cohesion of components.

To consider the classification of compound words, it is also necessary to clarify the term for the concept of "compound word".

The main purpose of this study is to provide scientific coverage of systemic semantic phenomena in the field of the selected word-formation subsystem of the Chechen language, to identify the internal laws of the composite word-formation system and the related regularities of semantic changes in derived units and the factors that determine them. This is done on the basis of the material provided directly by the language (mainly in its written manifestation), taking into account the information accumulated in the scientific literature on the issue of compound words in the Caucasian and other languages, which made it possible to characterize the Nakh word composition system in its current state and in its development. 


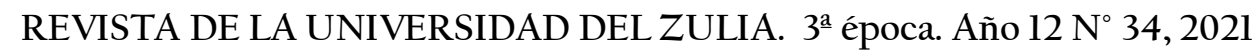

Marzhan U. Suleibanova et al// Heterogeneity of signs and classification criteria for compound... 558-571

DOI: http://dx.doi.org/10.46925//rdluz.34.30

In accordance with the set goal, the following specific tasks have been set and solved in the work:

1) to conduct a critical review of the main provisions in the interpretation of complex formations in Russian and Caucasian linguistics and establish the state of knowledge of this problem;

2) to reveal the national-linguistic peculiarity of the identification of a complex word in the Nakh languages;

3) to analyze the classification of complex formations proposed in linguistics and determine the optimal classification option for Nakh composites.

\section{Research Methods}

The article used the classification method, the descriptive method, and the techniques of linguistic analysis, which are widely used by all researchers working with the material of specific languages or linguistic groups.

The method of typological comparison used in this study should be especially highlighted, which confirms the sufficient efficiency when comparing languages of different genetic and structural affiliation. The specified research method has been successfully used in research devoted to one language or a group of languages; the consideration of which against the background of as many other languages as possible often makes it possible to identify and explain such facts and features of the studied language that could not be found without such a background.

\section{Results and discussion}

2.1. Classification of compound words according to the dominance components According to the tradition dating back to ancient times, Indian grammars establish four types of compound words, depending on the dominance of the components: the main thing in some composites is the meaning of the first element, the meaning of the second element in others, the main thing is the meaning controlled by an extraneous word in some, and the meaning of both components in the rest.

Indian grammarians have appropriately given them the following names: авьяйибхава, татпурша, бахуврихи, двандва. 
T.A. Chavchavadze, the author of the monograph "Nominal Composition in the New Persian Language," notes: "The types of compound words highlighted by the Indians can be stated in different languages and even languages of completely different origins, different systems. The Indian classification system of composites is universal due to its optimality" (Chavchavadze, 1981).

Thus, the characterization of compound words on this basis has a positive meaning from the point of view of the dominant role of the components of compound words. However, it is clearly insufficient to clarify the essential nature of compound words and the relationship of their components.

2.2. Classification of compound words by the presence or absence of a connecting element between components

This tradition is very strong in Russian linguistics.

In Russian, with the help of the vowels "o" and "e", components can be connected both in subordinate (снегопад, нефтеперерабатывающий) and in compositional (лесостепь, научно-технический) communication. Other elements can also act as a connecting morpheme (interfix):

a) after the bases of quantitative numerals, a connecting morpheme appears, homonymous with the ending of the genitive case of the numeral (пятилетка, двухтомник, трехрублевый, сорокалетний);

b) after the components дв(а) and пол - in a number of formations the interfix --y(двуногий, полугодие) is distinguished;

c) before the -метр component there is -и-(дозиметр, сантиметр);

d) after the stems of verbs, in some additions, a connecting morpheme is distinguished, homonymous with the ending of the imperative mood (перекати-поле, вертихвостка).

This classification is convenient for establishing the formal types of compound words, but according to this principle, it is impossible to reveal either the relationship or the lexical and grammatical nature of the components, and it is impossible to establish all varieties of compound words.

2.3. Classification of compound words by the lexical and grammatical nature of their components 
It helps to establish the structural features of compound words and to find out to which part of speech this or that component belongs, thereby to reveal the lexical and grammatical nature of compound words. It is this principle that, as a rule, is observed in the basis of the description of compound words in many scientific grammars. It can also be used to classify compound words in modern Nakh languages. According to the peculiarities of form, meaning and functions, Nakh compound words can be divided into three main morphological categories:

1) compound names (nouns, adjectives, pronouns, numbers);

2) compound verbs;

3) compound unchangeable parts of speech (including incomplete words).

Our research focuses on compound names (nouns and adjectives) and compound verbs; composites related to other parts of speech are considered in connection with other issues.

It should be borne in mind that there is no degree of cohesion of the components in this classification, i.e. the qualitative side of the most difficult word. We also believe that this principle is more suitable not for specific, but for subspecies classification.

2.4. Classification of compound words by the syntactic relationship of components

Researchers distinguish between two main types of compound words for this characteristic:

1) compositional - a combination of equal components;

2) subordinate - a combination of components, among which the main and dependent are distinguished (such a relation of components can be in the nature of a relationship between a definition and a defined or addition and a manager).

Determining the nature of the relationship between components, of course, helps to establish the essence of compound words, the degree of cohesion of components. Therefore, this principle is quite acceptable when studying word composition. However, when studying compound words, one should not directly transfer the syntactic relationships of words that exist in free phrases to the relationships of components, as is observed in some works.

\subsection{Classifications based on semantic characteristics}


In the research literature, there are also a number of classifications based on semantic characteristics. So, for example, T.B. Kuzminskaya finds it possible and convenient to divide compound words in modern Czech literary language into two groups based on the different ratio of the general meaning of the composite to the set of component meanings: nonidiomatic and idiomatic (Kuzminskaya, 1955). T.B. Kuzminskaya includes in the first group composites that are semantically equivalent to the corresponding phrases, and in the second - composites, the meanings of which, although usually based to a greater or lesser extent on the general meaning of the components, do not coincide with it and therefore cannot be derived from it.

In the study by M.D. Stepanova, based on the material of the German language, these linguistic units were respectively named "separately directed" and "whole-directed" compound words (Stepanova, 1953). Based on the degree of obscuration of their semantic motivation, she subdivides "whole-directed" compound words into three subtypes:

a) compound words, the semantic motivation of which can be considered completely obscured. The author believes that such words can be considered borderline in relation to the root, due to the complete semantic break of their components with the supporting words;

b) compound words, the semantic motivation of which is a conditional figurative characteristic of the designated object or phenomenon, in other words, a rethinking of one of the components or compounds, which, in general, are more or less clearly felt;

c) compound words, the components of which can be easily correlated, from a semantic point of view, with reference words.

According to the author, such a classification is, to a large extent, conditional, because it "does not cover all possible types of rethinking of components and compounds, in general, within this large and extremely productive class of words in the modern German language" (Stepanova, 1953).

Perhaps there is no language in which, to one degree or another, word composition is not used to express new concepts and grammatical categories. Some types predominate in some languages, and others in others; in some the word composition is more developed, in others less. E. Sapir correctly remarked about compound words and their types: "The variety of types of addition is amazing. These types vary according to the function, the nature of the elements and their order" (Sapir, 1934). 
REVISTA DE LA UNIVERSIDAD DEL ZULIA. $3^{a}$ época. Año $12 \mathrm{~N}^{\circ}$ 34, 2021

Marzhan U. Suleibanova et al// Heterogeneity of signs and classification criteria for compound... 558-571

DOI: http://dx.doi.org/10.46925//rdluz.34.30

There is an opinion among Caucasian scholars that compound words can be classified according to their structure, composition, semantics, origin of the members, communication methods, laws of education. However, the above features do not cover all types of compound words. For example, when classifying by structure, as well as by the ways of linking components or by syntactic criterion, such types of compound words as repetitions and compound words remain outside the classification.

Some features, such as, for example, semantics, composition and origin of components, can serve as the basis for intraspecific classification, in particular for the classification of compound words themselves. The basis for the classification of compound words is undoubtedly their difference in part of speech: we distinguish between compound nouns, adjectives, verbs, adverbs, pronouns, numerals, onomatopoeic words, etc. The study of each of the types distinguished by this feature is of certain interest. Using the material of the Nakh languages and the Caucasian languages in general, for example, it is interesting to trace how onomatopoeia are formed in general and in particular paired onomatopoeia. I.A. Mazanaev notes that sound-visual words are "widespread in the Caucasian languages" (Mazanaev, 1988), words formed by adding sound-visual words are rather wide.

The classifications of compound words can, as you know, come from various features; it is not easy to combine them in one work. One, representing the most important, giving the most complete picture of the object of research, should apparently be chosen for completeness of the analysis of the material. In this regard, it seems to us the most significant classification of compound words by the method of their formation. On this basis, five types of compound words can be distinguished in modern Nakh languages:

1) repetitions formed by repeating the same word or part of a word: Chechen кlайнкlайн Ingush кlей-кlей, "white-white", lаьржа-lаьржа "black-black", хаза-хаза "the most beautiful", дика-дика "the best"; Ingush хоза-хазагl "the most beautiful", дикадикагl "the best", etc. Similar paired formations - adjectives are used in both Vainakh languages and in another sense - "possessing this feature to the greatest extent than others, also having this quality"for example, кlайн-кlай "the whitest of the other whites". If one draws a conclusion, relying on the well-known dictionary of N. and D. Kadagidze, such paired formations, as well as paired composites in general in the Batsbi language, have not become widespread, while borrowings from the Georgian language are often used when 
REVISTA DE LA UNIVERSIDAD DEL ZULIA. $3^{a}$ época. Año $12 \mathrm{~N}^{\circ}$ 34, 2021

Marzhan U. Suleibanova et al// Heterogeneity of signs and classification criteria for compound... 558-571

DOI: http://dx.doi.org/10.46925//rdluz.34.30

naming the corresponding objects and concepts.

Obviously, in other cases related to the formation of words by means of constitution, there are clear similarities between Chechen and Ingush, on the one hand, and the Batsbi language, on the other, there are significant differences between these two conventional groups of Nakh languages.

The fact that the word-formation system of the Batsbi language is related to the Chechen and Ingush languages is, of course, the place that the method of foundation takes in it: this method is used and, according to all indications, was actively used in the past to replenish the vocabulary of the language in the Batsbi language. In this sense, one cannot agree with the point of view of G.A. Klimov, who asserted, referring to the Nakh languages, that "word composition plays a very modest role in nominal and especially in verbal word formation, which sharply opposes these languages to the Abkhaz-Adyg languages" (Klimov, 1986). This clearly contradicts the position postulated in Nakh linguistics that in the word formation of the Nakh languages the leading role belongs to compositing. But it's not only that. A similar opinion could also be formed due to the fact that, on the one hand, the word formation of the Nakh languages has been studied insufficiently, on the other hand, a line has not been drawn between phrases and compound words, therefore many facts of the formation of compound words in the Nakh languages could remain outside the field of view of researchers. In fact, as our material shows, there is little reason to talk about the "modest role" of word composition in the Batsbi and Vainakh languages, while the Batsbi language, apparently, even "leads" in the formation of compound words of individual lexicoderivational groups.

The grounds for such a conclusion are provided, for example, by the facts of the formation of compound words in the Batsbi language to designate such concepts that the Chechen and Ingush languages can only express by phrases or descriptive constructions: пстІунлин "married" (cf. Chechen зуда ялийна), пстІуйно "married woman" (Chechen доьзал, Ingush диезал "family" here is not equivalent to Batsbi пстІубадри,, since it means a family with her husband), нандад "parents; mother and father" (Chechen дай, наний), лам-бар "mountains and valleys; the whole world "(cf. Chechen дерриг дуьне; дуьне). On the other hand, in the Batsbi language, composite formations are noted to denote concepts expressed in the Vainakh languages in one word: dokImossin "evil, with an evil 
heart" (Chechen вуо ${ }^{\mathrm{H}}$ Ingush вуон; цимхара), докІдаккхо "arrogant, proud" (cf. Chechen and Ingush кура, сонта), etc. (Suleibanova, 2008).

On the other hand, as shown in the work on a fairly extensive material, wordformation types and structural models of individual composites, characteristic of the other two Nakh languages in the Batsbi language, are practically absent or represented by a smaller number of formations. Last but not least, this can be attributed to the significant influence of the Georgian language, from which the Batsbi language borrowed, as you know, about half of all words included in its vocabulary, including many semantic correspondences to the composite formations of the Chechen and Ingush languages.

2) paired words formed by pairing (combining) two different (but related in meaning) words: Chechen daar-malar "food, treat", literally “даaр-малар”, могуш-паргlaт "health, well-being”, literally "healthy-free”, Ingush даap-малар, могуш-паргlат; Chechen данана "parents" (literally "father-mother"), Ingush as well; шича-маьхча, ing. шуча-мохча (cousin-second cousin (brother; sister), кад-Іайг, Ingush кад-Іаг "kitchen utensils "(literally "bowl-spoon", муотт-гІайба "bed" (literally "bed-pillow") and others. In Batsbi, this type of paired formations also did not become widespread, although there are separate formations: нан-дад "раrents", literally "father-mother" (but in a different order - дад-нан - "grandmother"); usually such formations in the Batsbi language are a combination of two components, the first of which is a truncated form of the genitive case of the name, which coincides with the main (nominative), therefore, they are not pure additions and correspond to Chechen and Ingush composites such as денваша, денана: cf. Batsbi дадвашо "uncle (father's brother)", дадйешо "aunt (father's sister)"; one cannot but pay attention to the fact that in the Batsbi language some formations of this type fixed by the dictionary are noted, which are absent in Chechen and Ingush: йохь-вохь "girl and boy; daughter and son", марпстІу "spouses: husband and wife" (this concept in Chechen is conveyed by the compositional phrase зудий, майрий), for example (Kadagidze, 1984), lexicographed as compoundwords are not distinguished in Chechen and Ingush, although the combination itself is used when it comes, say, about the presence of someone, respectively two children girls and a boy (йоI, кІант "girl and boy", йоІ, кІант "boy and girl");

3) determinative compoundwords formed by combining two or more stems (they differ in a wide variety of particular models): латтаохкург "digger", дойлелориг "horse 
breeder", чилхьесан "silk"; Batsbi дабцІмакар "to be able to recognize; the possibility of recognition", докІпшелин "cold (man), from докI "heart" and пшелин "cold"; the widespread prevalence of determinative compoundwords in the Batsbi language is evidenced, for example, by the fact that with only the first component дакI-/дайкI-, used, as the authors of the corresponding dictionary note, as "a constituent part of compoundwords or phrases" (Kadagidze, 1984), the corresponding dictionary records more than 20 compound words.

4) compound-suffix words formed by addition and simultaneous affixation;

5) compound abbreviated words formed by reducing two or more bases: райисполком "regional executive committee", педсовет "pedagogical council", etc .; being borrowed from the Russian language, such compound words in the Chechen and Ingush languages do not have their own word-formation motivation, based on the corresponding components; the same applies to some correspondences of such words in the Batsbi language, which differ from the Chechen and Ingush words in a partially altered phonetic structure.

The third and fourth types of compound words not only received development in the Batsbi language, they are represented here even more widely than in Chechen and Ingush, taking into account the peculiarities of their formation and the fact that in the corresponding composites of the Batsbi language, as one of the components, stems borrowed from Georgian language words.

The division of compound words into certain types and the identification of specific properties and features that distinguish them from each other is of great theoretical and practical importance. This makes it possible to specifically judge each of their types, to comprehensively study the specific properties and characteristics that distinguish one or another species from other compound formations.

\section{Conclusion}

Compound words are one of the most important objects of study in word formation. Particularly important is increased attention to them when it comes to languages in which affixation is limited and the expansion of the vocabulary occurs mainly by merging two or more words into one.

It should be expected that the formation of words in this way obeys some general laws, 
occurs according to models and "principles of form formation" similar for different languages, and along with this, each language shows its own specific features in the implementation of these general principles and models. The study of word formation in the Nakh and foreignstructural languages (of which the Russian language is most actively compared with the Chechen and Nakh languages in general), allows us to conclude that they use common methods of forming new lexical units (words): a) word production, 6) compounding.

In each of these methods, one can find signs common to all these languages, including the Russian language, which form that stable set of interrelated and interdependent characteristics, which it seems possible to call the "type of word formation".

The most important and easily identifiable difference when comparing the wordformation systems of the Chechen and Russian, for example, languages, is that of the two named main ways of forming words (word production and fundamental formation), the second clearly prevails in the Chechen language. The reliance of the Chechen word formation on the basis is not a new phenomenon and not a specificity of the Chechen language. It is known that in many languages, word-formation affixes historically go back to the components of additions. Consequently, compounding precedes affixation. This phenomenon does not speak in favor of the position that the archaic nature of the language is the reason for the spread of word composition, and, conversely, if we proceed from this position, then the archaism of the language should serve as the reason for the spread of affixation as a secondary stage in the development of language, a stage of higher abstraction and technization of linguistic elements ... With regard to the Nakh languages, it can be argued that these languages have, since ancient times, a method of constitution, rooted in the period of the amorphous structure of these languages. This is evidenced by the compound toponyms of the mountainous strip of Chechnya and Ingushetia, in which there are no traces of material indicators of grammatical forms (Пхьамта, пхьакочи, etc.). New nouns in the past most often arose by adding the stems of two or more nouns (белш-корта - "the head of the humerus", церг-ков - "nick", etc.).

On the other hand, the activation of composite word formation in many languages, including the Nakh languages we are studying, as well as in the Slavic number of RomanoGermanic languages, a significant expansion of the proportion of vocabulary formed in this way in them, suggests that, apparently, to raise the question in the plane of precedence of 
compound words to lexical units formed by the suffix method is not entirely correct. It must be assumed that each language or group of languages at the time of their formation had their own peculiarities of the formation and development of signs of the grammatical structure, in particular, the choice of the leading methods and means of forming words, but, nevertheless, the addition or fusion of two or more words in any the case took a certain place in them.

Structurally and genetically, composites in the Nakh languages go back to syntactic combinations of words that are agglutinatively fused into one word as a result of prolonged and frequent use.

We had to choose from a variety of known a certain classification principle, which is designed to help reveal the material nature, semantic essence and degree of cohesion of components for further in-depth analysis of composite formations in the Chechen language. The most acceptable basic classification of such units is the classification of compound words by the way they are formed. On this basis, as noted in the chapter, the following are distinguished: 1) repetitions formed by repeating the same word or part of a word (кlайнкlайн "white-white", lаьржа-lаьржа "black-black", хаза-хаза "the most beautiful", дикадика "the best") ; 2) paired words formed by pairing (combining) two different (but related in meaning) words (даар-малар "food, treat", literally "food-drink", могуш-паргат "health, well-being"); 3) determinative compoundwords formed by combining two or more stems (they are distinguished by a wide variety of particular models); 4) compound suffix words formed by addition and simultaneous affixation; 5) compoundabbreviated words formed by reducing two or more bases: райисполком "regional executive committee", педсовет "pedagogical council", etc ;) being borrowed from the Russian language, such compound words in the Chechen and Ingush languages do not have their own wordformation motivation, based on the corresponding components; the same can be said about the compound-abbreviated words in the Batsbi language, into which they entered not directly from the Russian language, but through the Georgian language.

\section{References}

Chavchavadze, T.A. (1981). Nominational Composition in the New Persian Language. Tbilisi: Metsniereba,. $375 \mathrm{p}$. 


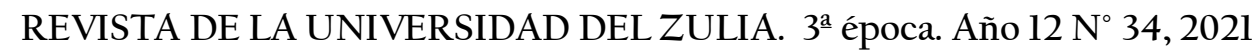

Marzhan U. Suleibanova et al// Heterogeneity of signs and classification criteria for compound... 558-571

DOI: http://dx.doi.org/10.46925//rdluz.34.30

Kadagidze, N. (1984) Tsova-Tushino-Georgian-Russian dictionary. Prepared for publication by R.R.Gagua. Tbilisi: Metsniereba, 935 p.

Klimov, G.A. (1986) Introduction to Caucasian Linguistics. Moscow, 208 p.

Kuzminskaya, T.B. (1955) Compoundwords in modern Czech literary language: Diss. Cand. Kiev, 280 p.

Marchand, H. (1960) Substantial composites-bachuvrihs of the anthroposemic field in English.

Mazanaev, I.A. (1988) Morphological features of Lezgi sound-visual words. Questions of the morphology of the Russian and Dagestan languages. Interuniversity scientific-thematic collection. Makhachkala, DSU publishing house, Pp. 108-114.

Sapir, E. (1934) Language. Introduction to the study of speech. Moscow - Leningrad: Sotsekgiz, $223 \mathrm{p}$.

Stepanova, M.D. (1953) Word formation of the modern German language. Moscow: Publishing house of literature in foreign languages, $374 \mathrm{p}$.

Suleibanova, M.U. (2008) Nominal and verbal composites in Nakh and foreign languages. Grozny. 165 p. 